Editorial

\title{
Power and democracy in Iceland: An introduction
}

\author{
Guðmundur Heiðar Frímannsson, Professor of philosophy, School of \\ Humanities and Social Science, University of Akureyri
}

Democracy is a complex subject and power is no simpler. In the research project Power and democracy these two constitutive facts of Icelandic society are investigated from various points of view. This research project which results are presented in this special issue of Icelandic Review of Politics and Administration has been going on since 2014. It has resulted in various theoretical articles published earlier. This special issue is not a final report of an investigation into power and democracy in Iceland as has been published in other Nordic countries. The funds received for this project were more limited than political scientists received in other Nordic countries to conduct similar investigations of their own governing structures. The results are varied and do not form a coherent whole but they are interesting in their own right. This special issue marks the ultimate point in the research project.

All the articles engage with various features of Icelandic democracy, be it the machinery of state, Icelandic power structure, political parties or the changing social background of the citizens and their relations to the Icelandic state. All except one are empirical investigations of Icelandic democracy. Árnason's paper is about the normative features of Icelandic democracy interweaving philosophical explorations with empirical facts and interpretations of probably the most important political event in recent Icelandic history. As most of the papers in this volume Árnason's takes notice of the financial collapse in Iceland in 2008. An obvious question is: Why is this event important for theoretical investigations into Icelandic government and politics, power and democracy in Iceland now ten years after the collapse? It is difficult to explain for outsiders why the financial collapse is so penetrating for Icelanders and why it is still politically potent. The first thing to notice is that the collapse is not a single event but a fairly long series of

Icelandic Review of Politics and Administration. Vol. 14, Issue 1. Special issue on power and democracy in Iceland (I-X) (C) 2018 Contact: Guðmundur Heiðar Frímannsson, ghf@unak.is

Article first published online May $31^{\text {st }} 2018$ on http://www.irpa.is

Publisher: Institute of Public Administration and Politics, Gimli, Sæmundargötu 1, 101 Reykjavík, Iceland

Stjórnmál \& stjórnsýsla. 1. tbl. 14. árg. 2018. Sérhefti um vald og lýđræđi á Íslandi (I-X)

(C) 2018 Tengiliður: Guðmundur Heiðar Frímannsson, ghf@unak.is

Vefbirting 31. maí 2018 - Birtist á vefnum http://www.irpa.is

Útgefandi: Stofnun stjórnsýslufræđa og stjórnmála, Gimli, Sæmundargötu 1, 101 Reykjavík

DOI: https://doi.org/10.13177/irpa.a.2018.14.1.11

This work is licensed under a Creative Commons Attribution 3.0 License. 
events that have no single meaning. There had been continuous growth of the Icelandic economy for many years and the government at the time had argued that international finance was the new way for Icelanders to prosper. The president had delivered speech after speech saying that Icelanders had discovered a new method for making money, the Viking method. The financial system grew at enormous speed impacting most other spheres of life in the country, spreading money wherever the new financial wizards went, into culture, academia, the media. Then, suddenly, one October day, the sixth to be precise, the growth disappeared and the whole financial system collapsed. The three largest banks went bust in one week along with other smaller financial institutions. In the afternoon of the sixth of October, the prime minister gave a speech telling the nation that there was a danger of national bankruptcy if the Icelandic state guaranteed the loss of the banks indicating that the nation's independence and sovereignty might be in danger because the banks owed such enormous sums to financial institutions in other countries. ${ }^{1}$ He ended his speech like an American president saying: God bless Iceland.

What had really happened? The three largest banks had grown so enormously that their combined wealth amounted to ten GNPs. There was no possibility for the Icelandic state to back all the three largest banks. The hope was that one of them might be saved, Kaupthing, but that turned out to be impossible. I do not intend to go into any details in this story because it is not necessary in this context. But the important thing to notice is that suddenly Icelandic citizens felt they saw with their own eyes their representatives in government and parliament as blundering idiots, morally corrupt, ready to act on behalf of special interests but having neglected the common good in the years leading up to the collapse. It was not a pretty sight and the citizens were shocked. They still are as some of the contributions to this volume demonstrate. Admittedly, this is an impression not backed by social research but something of this sort must have happened if we are to make sense of the political fallout of the financial collapse in Iceland. It must also be kept in mind that Icelandic politicians managed the economy, including the saving of the banking system in 2008-2009, well enough to secure a strong and steady growth so that now the Icelandic economy is in better shape than in the years leading up to the collapse in 2008.

A background fact to these events is that Icelandic politics in the twentieth century, ever since the 1930s was a very special practice meaning that parliament and the political parties controlled much of public society in Iceland. They controlled the public radio and later television, while private radio and television was banned, through a politically appointed board controlling both the hiring of staff and programs, banking was controlled through politically appointed boards with members of parliament being in charge of public banks often using this position for political purposes. Ministers of government could appoint specialists to their ministry without any restraint of law and the same applied to appointments to the courts, the minister of education appointed all academic staff to the University of Iceland until 1989, and it was only in the final decade or so that evaluation committees put any pressure on the minister. This is not said to point a finger at any political party but only to describe a part of the political system in 
celand that all political parties accepted. All of this may be common facts for Icelanders but for those not knowing much about Icelandic political culture these facts can make clearer some of the weaknesses of the public political system some of which are still in place and being fought about. Hopefully, this might enable them to appreciate how skewed and special political culture was in the decades leading up to the 1990s when Iceland entered the European Economic Area. Then it had to start adapting to modern conventions in democratic practices and one of the first things Icelandic politicians had to do was to let go of the banks. They were sold to private individuals and we know now that that this was not done in a proper manner. One of the buyers got away with lies and manipulations, none of them had to pay out of their own pocket for the banks but they lent each other money to pay for their shares. This meant that there was a risk built into the system as a whole, the fate of the three major banks was closely linked but the state did not put any pressure on the buyers to certify that they were using their own money, those governing the state did not know how the financiers were financing their buying of the banks. The basic idea seems to have been laissez faire on behalf of the state believing there was no need to control or regulate the banking system strictly. Similar developments in this field occurred in other European countries at the time but not in the other Nordic countries. There the state followed closely what happened in the banks and most of them survived. In Iceland there was no tradition of controlling a large banking sector. Some of the buyers turned out to be bent and incompetent and some of them ended in jail in the years after the collapse in 2008. All of them lost a lot of money and the political culture lost its innocence after being clientelistic and corrupt for decades. The citizens enjoyed this system, supported the politicians promoting the growth of the banks as long as "their" politicians were in power. This is a well-known pattern in research on political corruption. Most of the citizens have not recovered but some of them have not yet fathomed what really happened.

Árnason uses three models of democracy, liberal, republican and deliberative, to interpret and understand the course of events leading up to the financial collapse and the years after. It turns out that all of the theories are needed to understand the ideas driving the political agents. He also looks further back to understand the present Icelandic political culture, even to the nineteenth century and the politics of independence practised at that time.

Vilhelmsdóttir and Kristinsson ask the question what the relationship is between economic growth and trust in government. Usually, the relation is that the better the economic growth the more trust. It should come as no surprise that trust in politicians and bankers plummeted in 2008 and 2009. The same applies to trust in some of the political institutions. The interesting thing is that Iceland has recovered economically fairly quickly after the collapse, but trust has not followed the economic recovery. This is intriguing but maybe it should come as no surprise. It must be said that the political culture has not changed, its superficiality is still there, it is still "characterized by partisan bickering" as Árnason expresses it. There is still the tendency to speak with two tongues, one when you are in government, another when you are in opposition, and even though 


\section{STJÓRNSÝSLA}

some of the things you say in opposition contradict what you say when in government the politicians just shrug their shoulders seemingly saying this is how we do things. The problem is that behaving like this is an insult to the rationality of the citizens. And it is demeaning for the political culture and those who care for it. Vilhelmsdóttir and Kristinsson find that for those groups hardest hit by the financial collapse "the crisis may have been a critical experience creating a sense of alienation towards the political forces." Another cause preventing the rise of trust in the political system is the political volatility after the financial crash. Even though trust is one of the most basic things in human affairs it is one of the most difficult to understand.

There are various structures that shape democracy and power in the Icelandic system of government. One of them is local authorities, the lower level of the two-tiered government in Iceland. Local government has a long history in Iceland, it has been with us for a thousand years at least. In 930 Icelanders established a state or at least a general government for the whole country. It seems that "hreppar," the old units of local government, came into being a little later and from the beginning they were responsible for the welfare of people living in their area. These old units have now been transformed into new local authorities but many of them still survive. In the old units it was assumed that local government was sovereign in the sense that the leader could decide what to do and how the local authority executed its obligations. This old tradition lives on in the fact that Icelandic politicians in parliament have never been willing to use the power of the state to determine the size and territory of each local authority. In recent decades there has been constant pressure on local authorities in Iceland to take on more functions from central government. Because there has been no political will to use the authority of parliament to enlarge the territory of each local government what has happened is that the central government has pushed various functions on to the local level and left the representatives there to deal with it. This has certainly created pressure within the local authorities to amalgamate with others creating larger units developing more professional bureaucracies enabling them to handle more complex functions. Sometimes the local authorities have decided to cooperate rather than to amalgamate. However, they will develop in the near future they will grow bigger to be able to service the needs of the citizens and they will also become more professional and, hopefully, restrain the power of the local councillors.

Another structure that shapes Icelandic politics is corporatism, the involvement of agents outside government that represent some relevant interest. This is a feature of the exercise of power of central government in all the Scandinavian countries and it applies to Iceland as well. Indeed, I think we should expect corporatism in political systems that are consensual. The reason is that corporatism is one way of involving those who are representing powerful organised groups in such societies in public decisions with the foreseeable consequence that the decisions taken are in line with the will and wishes of these powerful groups avoiding conflict and disunity in society. Corporatism is a part of the policy process and it can both involve the formulation of policy before a decision is taken and it can be a part of the implementation process. The problematic aspect of 


\section{STJÓRNSÝSLA}

corporatism is that it is only those organisations powerful enough that are offered a seat at the political policy table but not the ordinary citizens themselves. If the policy process is about discovering the common good, then it seems more reasonable to expect the citizens to be able to discover the common good rather than those who represent large groups or organisations. Alternatively, the bureaucrats should be equipped with the skills to divine the common good independently of any organised interest in society.

It is somewhat surprising that Iceland has developed differently from the other Nordic countries but in Óskarsdóttir's investigation of Icelandic corporatism it turns out that other Nordic countries have limited the number of public committees including members representing organized interests while they have increased in number in Iceland. She investigates the time from 1970 until 2017. This means that corporatism in Iceland is still strong while it has weakened in the other Nordic countries. This is a significant new fact about Icelandic government. It is not quite clear why this is so, but one suggestion might be that in Iceland the executive branch of government has traditionally been weaker than in other Nordic countries and it might not be able to handle the role of formulating policy and implementing it properly without the support of organized interests in society.

Another structural feature of Icelandic government is ministerial government. Ministerial government is government by ministers who are independent of each other and do not take collective responsibility for each other's decisions. Their actions and decisions are not subject to approval of the government as a whole and even though it is supposed to function as an arena for discussion then this limited restraint does not really happen because the bills are only introduced at meetings without giving other ministers time to read. The major problem for this kind of government is the temptation for each minister to propose bills that ministers of coalition parties are unable to accept. This temptation might be a force sufficiently strong to break up governments at any moment in its life. But there have been other forces at work preventing this temptation to take hold of headstrong ministers. Indriðason and Kristinsson's examination of this issue draws out that before the 2008 financial collapse Alpingi played an unusually active role in processing government bills, short ideological distance between the coalition parties helped and strong cohesion of each coalition party contributed to commitment to the government. Then they add: "Part of making this system work involved allowing lobbyists of various kinds relatively unfettered access to Alpingi so that interests associated with the different coalition partners could have a say in how government bills developed."

After the financial collapse, this has changed because some effective mechanism supporting collective government are in place, things like long coalition agreements and increased attention to hierarchy. But Alpingi is still a major place for lobbyism. It is interesting to note that lobbyists get the access they want to Alpingi, meaning that they can support the initiatives of their parties and ministers without any regulation. This points to the close connection between organized interests and the parties in parliament and is in line with the fact that corporatism is another way of allowing the influence of 
organized interests in government. This indicates the strong and active role of organizations, businesses and other organized interests in shaping public policy in Iceland. The worrying thing is that this seems to be unregulated.

The major actors on the political scene are the political parties. They serve the vital function of giving the citizens a formulation of a set of political views that they can identify with. A modern representative democracy would be ungovernable without political parties. If we assumed that all the representatives in Alpingi were elected as individuals but not as parts of groups, they would have to negotiate all issues between the 63 members rather than as parties coming to an agreement that supported a government relying on the consent of the members of the coalition parties. It is conceivable that the 63 might form a government, but it is unlikely. One possible result might be that all government would be bureaucratic in the sense that the executive branch would become independent of the legislative branch because Alpingi could not function as a policy decision chamber for the executive branch. It would take far too much time to come to agreement about even the smallest things. Fortunately, this is not likely to happen, political parties are still alive and well and serve the interests of citizens even though they are not perfect vehicles of the common good. Önnudóttir and Harðarson investigate the long-term changes in two cleavages of Icelandic political life, the urban/ country cleavage and the left/right cleavage. They look at 33 years of voting behaviour to see if there are any changes in these two cleavages and also if there are changes in party identification and its influence on voting.

They find that there are not substantial changes in the cleavages, they are still relevant for citizens today as they were 33 years ago. Political parties must take notice of them in their decisions and their policy formation in so far as Icelandic political parties formulate policies they take seriously and pursue in their political work. But party identification has changed during the time this research spans, it has weakened, and political parties cannot depend on their supporters' loyalty as they could before. It also seems to be true that socio-economic status does not influence the citizens' decisions in voting as it did earlier on. These results are important, and they make life more complicated for the political parties, they must stretch themselves to reach new voters but at the same time satisfy their core supporters.

One of the things that has changed in the last decades is that the citizens have become more diverse. Immigration to Iceland has increased since the turn of the century and now they constitute about $10 \%$ of the population. This is a major change from a uniform society of white descendants of immigrants to Iceland about 1100 years ago, to a society of people from various places of the world with backgrounds that influence their attitudes, desires and behaviour making them different from the local population. This development was well on the way before the financial collapse in 2008 and in the aftermath of it many immigrants lost their jobs. Most Icelanders had welcomed the newcomers before 2008 and the problems in the labour market after 2008 did not change that, and still the most widespread attitude is to welcome the immigrants. This is not to say that they do not have problems, they certainly do and there are prejudices. 
But on the whole, they are welcomed and there does not seem to be any fertile ground in Iceland for the populism prominent in a number of European countries at the moment.

Einarsdóttir, Heijstra and Rafnsdóttir investigate the integration of immigrants into Icelandic society asking how successful we are at making immigrants citizens of Iceland. The answer is that this process is relatively successful but there are things that need improving. They concentrate on three groups of immigrants: Lithuanians, Poles and Filipinos. The first two groups can move to Iceland without any problems because of the European Economic Area guaranteeing freedom of movement for people among other things. But Filipinos must get permission from the authorities to stay in Iceland. It is interesting to see that the Filipinos adapt better than the other two groups to Icelandic society. It is imperative to integrate the immigrants into the political process so that they enjoy their citizenship to the full.

The citizens of any democracy have to have a media that they can trust, a media that takes truth seriously and attempts to serve the interests of the citizens, informing them of the relevant and important facts in the democratic system they are living in. There must be certain things in place for the citizens to trust the media, the media's owners must be reliable and not ready to limit the freedom of the journalists when it serves their interests. This does not only apply to privately owned media but also to the public media. Even though the state-owned media in Iceland enjoys the trust of many more citizens than the privately owned it can be subject to interferences by the political authorities. This happened regularly in the past, but times have admittedly changed and now the public media has been more independent than before, hence possibly, its higher trust.

Jóhannsdóttir and Ólafsson investigate the struggle of the Icelandic media because of technological developments, web-based media are competing with traditional newspapers and it seems that in the not too distant future there will not be any newspapers in Iceland, i.e. printed media. There is fiercer international competition for the money from advertising, especially from Google and Facebook. It is not only that the media must serve the interests of the citizens, but it is also important for a small nation like the Icelandic one speaking its own language. Media serves the public discourse in Icelandic of Icelandic citizens. In all probability the media will be supported by the state fairly soon to secure a vital element in public culture.

Power is not something you see or hear but one can discern it from various indications in society. Buildings can indicate power, institutions can embody power and so can individuals. Groups are probably most often vehicles of power, sometimes the groups are formal like the group of judges at a court or parliamentarians in parliament. Democracy in its present guise does not exclude power but puts a limit on its exercise because human rights are now a well-established part of modern democracy. But it is certainly possible to define democracy as majority rule and nothing more. In that case the majority can do anything it wants, i.e. the power of the majority is unlimited. But defining democracy in that way is not practised anywhere even though the majority has vast powers in some states. The problem with this definition is that democracy could not properly 
function if it only consisted of majority rule. The citizens must be free equals for democracy to be a benefit for them. They must be able to express their opinions without fear and without putting their lives in danger and the democratic system must be based on the notion of one citizen one vote or some other equivalent interpretation of equality. Democracy in this sense is compatible with power because democracy is not anarchy.

Kristinsson in a path breaking research investigates power in Icelandic society. Power is expressed in elite groups and their resources as it is conceived in this research. It is not an investigation into the exercise of power but in how power is structured in elite groups in Icelandic society. The elitism seems to have developed from traditional elitism based on kinship ties and social exclusion in the early twentieth century, through competitive elitism to professional pluralism in the early twenty first century. This elite system excluded women at first and is still skewed against women, meaning that women have not achieved the same status as men in the elite system although gender differences are decreasing. The elite system has also become more meritocratic as professionalism increased and the system has become more open. Education is one of the criteria for inclusion in the elite as it is a necessary feature of professionalism and it is closely related to social and economic status.

Pórhallsson investigates the shelter theory explaining the need of small states to have a larger state as its protector. His paper is the only one dealing with Iceland's relations with other states. Small states need active involvement with other states both commercially, industrially and politically. They have no way of resisting the force, financial or military, of larger states. Their only hope to stay independent and sovereign is to negotiate a protective contract with a larger state, a state that is willing to assist its smaller neighbour or protectorate when the going gets rough in the international waters for the small state. States are not benevolent actors taking on responsibility out of the goodness of their hearts but are selfish or governed by their own interest in whatever they do. When they take on a responsibility for another state, albeit a smaller one, they must get something in return. One thing they automatically get is increased influence in their sphere of control, their area of influence might become bigger and they might be able to influence the course of events farther afield than before. Or they might ask for access, military or otherwise, to the protectorate. Taking a small state under its wings might also be a matter of prestige. Whatever it is, the large states gets in return it is something of value to it.

As should be clear from Dórhallsson's article the event in 2006 when the last air force jets left Iceland against the will of the Icelandic government was significant in the history of the relation between Iceland and the United States. The judgement of the US government was that these jets were needed in other parts of the world and served the interests of the US better by being stationed there. At the time the Northern Atlantic was peaceful, and no obvious threat seemed to be able to endanger Iceland's security. In the twelve years that have passed, Icelandic governments have managed to negotiate agreements with various states about Icelandic air defence and safety in the waters around Iceland. At the same time, they have said that the defence agreement with the 
US is the most important pillar of Icelandic defence arrangements. All this is consistent with the shelter theory. Meaning that in actual fact a tiny state like Iceland must make arrangements for its own defence in collaboration with friendly states, but keeping up the appearances that the US is still the most valuable partner for Icelandic defence on land, sea and in the air. The jury seems still to be out if the time of the Pax Americana in the North Atlantic is over or has a future. If it is over Iceland will need another shelter.

Are there any general results about Icelandic government that we see in these investigations? There are some that we can mention at the end. The first is that the political system is going through a volatile period making governing more difficult that it was for a long time in Iceland. Trust is low in politicians and political institutions and party loyalty is weaker than it used to be. Second, Icelandic government needs the back up of large organisations to govern successfully. The obvious reason for corporatism to be as widespread as it is, is probably that the government is not strong enough. We might even expect an increase in corporatism because of the difficulties in governing. Third, we seem to be doing something right about immigrants even though there is room for improvement. Fourth, political life has become more problematic for the citizens because the political institutions cannot not always be trusted and the media is much weaker than before and tends to serve private interests, often neglecting its public role as a resource for the citizens of reliable information. Fifth, the power structure seems to developing into more professionalism, away from nepotism and corruption. Lastly, the local government might be developing into bigger units but it will go slowly.

I hope the readers of this volume enjoy the articles as much as I have done in editing them. They are a major contribution to political research in Iceland.

\section{Note}

1 See https://www.stjornarradid.is/efst-a-baugi/frettir/stok-frett/2008/10/06/Avarp-forsaetisradherra-vegna-serstakra-adstaedna-a-fjarmalamarkadi/ 
